\title{
Study on Energy Requirement of Wood Chip Compaction
}

\section{Analiza energije potrebne za prešanje peleta}

\author{
Professional paper • Stručni rad \\ Received-prispjelo: 7. 3. 2014. \\ Accepted-prihvaćeno: 20. 5. 2015. \\ UDK: $630 * 861.02$; \\ doi:10.5552/drind.2015.1409
}

\begin{abstract}
In order to utilize waste products such as sawdust and chips in the wood industry, pellets are made using compaction pressures in the range of $100 \mathrm{MPa}$ or higher. During the compaction process, the density and the modulus of elasticity of the material rapidly increase. Wood materials generally show non-linear viscoelasticplastic behavior and, therefore, the pressure-deformation relationship is dependent on the loading velocity and on the time during which the material is subjected to constant deformation or load. The energy requirement of pellet production depends on many influencing factors and in such cases the use of dimensionless numbers in the form of similarity equation facilitates the processing of experimental results and the obtained similarity relationship has a more general validity for the users. Various fractions of different wood species were used in these experiments, and the pressure, pellet diameter, temperature were also varied. The proposed similarity equation shows a good correlation with the experimental results.
\end{abstract}

Key words: chip fraction, compaction, pellet diameter, temperature effect, compaction work, dimensionless numbers

SAŽETAK • U praksi se često od poljoprivrednih ili drvnih materijala prešanjem usitnjenog materijala pod visokim tlakom proizvode pelete pri čemu je tlak često jednak ili veći od $100 \mathrm{MPa}$. Tijekom prešanja gustoća peleta brzo raste, a zajedno s njom povećava se i modul elastičnosti. Drvo i od njega proizvedeni peleti ponašaju se viskoelastično, tj. njihova tlačna deformacija ovisi o vremenu odnosno brzini opterećenja. Prijašnja istraživanja prešanja usitnjenoga drvnog ostatka pokazala su da cjelovito drvo ni tijekom prilično male kompresije ne pokazuje obilježja elastičnosti prema Hookeovu zakonu. Na kraju ciklusa opterećenja uvijek se zadrži određeni stupanj deformacije, a postupkom rasterećenja velik je dio deformacije nepovratan. Osim vremenom, odnos naprezanja $i$ deformacije određen je $i$ veličinom naprezanja tako da se ne može govoriti o linearnoj viskoelastičnosti. Na temelju rezultata provedenih istraživanja nastala je jednadžba prema kriteriju bezdimenzionalnosti koja univerzalno (neovisno o vrsti drva) karakterizira promjenu gustoće i pritiska s obzirom na prešanje $i$ temperaturu prešanja usitnjenoga drvnog ostatka i dobivenog peleta različitog promjera. Osim toga, istom se jednadžbom može utvrditi karakteristična energija pri izradi peleta ovisno o pritisku prešanja.

Ključne riječi: prešanje, viskoelastičnost, specifični rad, bezdimenzionalni brojevi

\section{INTRODUCTION}

\section{UVOD}

A rational utilization of waste products in the wood industry is to make them into pellets. The pelleting reduces the volume of the bulk chip considerably and facilitates its handling (transport, storage, feeding into boiler) fundamentally. At the same time, energy and suitable equipment are needed to perform the pelleting process. The most commonly used pelleting machines use a rotating die ring and the material is pressed into the boreholes of the ring by rollers. The first comprehensive

\footnotetext{
${ }^{1}$ Authors are PhD student and professor at Institute of Machinery and Mechatronics, University of West Hungary, Sopron, Hungary.

${ }^{1}$ Autori su doktorand i profesor Sveučilišta zapadne Mađarske, Institut za strojeve i mehatroniku, Sopron, Mađarska.
} 
analysis of the pelleting process is given by Schwanghart, (1969). Focus was placed on measuring and analyzing the working principle of the press rollers and the effect of their operational parameters on the throughput. For describing the compaction process, a relatively simple empirical relationship was used. Using non-linear rheological models, a more generally valid description of the compaction process was developed and used for sawdust and chips (Sitkei, 1994; Sitkei, 1997) and, furthermore, the non-linear viscoelastic behavior of the material was experimentally mapped in the entire loading velocity range. Some experimental results on the energy requirement of the pelleting process for fodder flours were already summarized by (Schwanghart, 1969) without specifying the measurement conditions and material properties. Later experiments also failed to give generally valid relationships for the energy requirement of the pelleting process (Carlos et al., 2010).

The aim of the present work is to develop and validate a relationship which takes into account the pressure, the final density of the pellet, pellet diameter, the effect of temperature and material properties. For this purpose, the application of similarity equation seems to be the most promising method, similarly to those successfully applied in the last hundred years in the field of heat transfer and fluid flow problems.

\section{THEORETICAL CONSIDERATIONS}

\section{TEORIJSKA OSNOVA}

Biological materials have very complicated material laws and, in the case of higher volume changes as is the pelleting process, the stress-strain relationship is always highly non-linear. Therefore, pure mathematical methods for describing the compaction process in all its details are today hardly available. A more practical and reliable approach is to perform carefully designed experimental measurements and to process these results in such a way that the obtained relationship would be valid with as few constraints as possible. In order to extend the validity of a relationship for different materials, it is necessary to include the proper material properties.

The particles in the ring die channels are loaded by compressive forces and, therefore, the material property may be characterized, as a first approximation, by the compressive strength of the material in question. Concerning the compaction process of wood chips, the following main influencing factors should be treated: material property of wood species, average particle diameter, compaction pressure, temperature of the material, diameter of the pellet, and final density of the pellet and the total specific work of compaction. There are further influencing factors with limited variability range due to the process itself. For instance, the loading speed has always a definite influence on the compaction process, but in real pelleting machines the loading speed can not be varied as a process parameter. The moisture content is also an important process parameter, but its range is also limited due to the durability requirement of the pellet.
Keeping in mind the above statements, the following formal functional relationship with seven variables may be written:

$$
W=f\left(p, y, d, \sigma_{C}, \vartheta_{0}\right)
$$

where:

$p$ - pressure, $\mathrm{N} / \mathrm{m}^{2}$

$W$ - total specific energy of compaction, $\mathrm{Nm} / \mathrm{m}^{3}$

$\gamma$ - final specific weight of the pellet, $\mathrm{N} / \mathrm{m}^{3}$

$d$-diameter of the pellet, $\mathrm{m}$

$\sigma_{c}$-compressive strength of the wood, $\mathrm{N} / \mathrm{m}^{2}$

$\vartheta$, $\vartheta_{0}$-the pellet temperature and a reference temperature, here taken as $\vartheta_{0}=25^{\circ} \mathrm{C}$ (room temperature)

In order to derive the proper functional form of Eq. (1), the standard dimensional analysis method was used (Buckingham, 1914; Langhaar, 1951). It yields the following dimensionless numbers

$$
\pi_{1}=\frac{W}{p} ; \quad \pi_{2}=\frac{\gamma \cdot d}{\sigma_{C}} ; \quad \pi_{3}=\frac{\vartheta}{\vartheta_{0}}
$$

and according to Buckingham's theorem, we may further write

$$
\frac{W}{p}=f\left(\frac{\gamma \cdot d}{\sigma_{C}}, \frac{\vartheta}{\vartheta_{0}}\right)
$$

or

$$
\frac{W}{p}=\text { const } \cdot\left(\frac{\gamma \cdot d}{\sigma_{C}}\right)^{n} \cdot\left(\frac{\vartheta}{\vartheta_{0}}\right)^{m}
$$

where the constant and the exponents $n$ and $m$ should be determined experimentally.

In the above equation, the dependent variable is the specific energy consumption $W$, therefore, the dimensionless number $\pi_{1}$ containing the specific energy is placed on the left side of Eq. (2). The other two numbers containing only independent variables are on the right side of Eq. (2). The total work of compaction is determined by the pure compression work and by the work done during pushing out the pellet from the boreholes.

The pure compression work is given by integration of the pressure along the displacement. The pressure-strain relationship is strongly non-linear and can be given in the following form (Sitkei, 1994; Pronk, 2005):

$$
p=A \cdot\left(\frac{\varepsilon}{1-\varepsilon}\right)^{n}
$$

where:

$A$ - material dependent constant

$n$ - exponent

$\varepsilon-$ strain.

The exponent $n$ depends on the size and strength of particles and on the pressure range. Its value varies between 1.5 and 2.5 for various wood chips (Sitkei, 1994; Hofko, 2008). The strength of chips especially influences the course of compaction curve as a function of displacement. Soft particles can be compacted at relatively low pressures and, increasing further the pressure, the curve ascends steep giving a higher exponent. On the contrary, particles of hardwood species with higher individual strength will be compacted more 


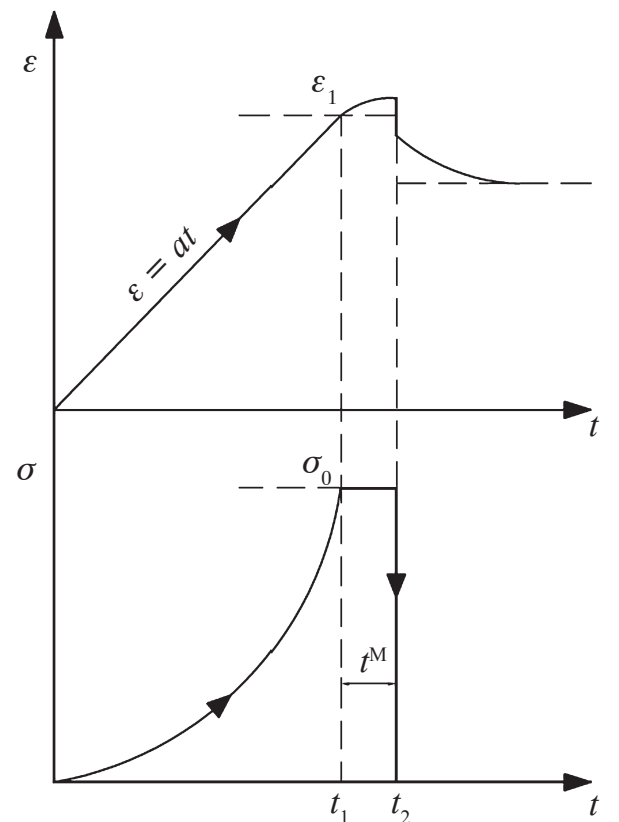

Figure 1 Time course of the compression process (Sitkei, 1994)

Slika 1. Vremenski tijek procesa kompresije (Sitkei, 1994.)

uniformly as a function of displacement resulting in lower exponent $n$. Due to the anatomical structure of wood, the individual strength of particles depends not only on wood species but also on the size of particles. With decreasing particle size, the surface-volume ratio increases (Csanády et al., 2013; R.C. Akdeniz et al., 2013). The surface of a particle is created by fracture with highly uneven surface and the load-bearing capacity of this near-surface layer is less compared to that of the sound inner part. As a consequence, a smaller particle may behave similarly as if it originated from a softer wood species. The effect of size on the compaction process can only be determined experimentally.

The second main part of the total compaction work is the work done during the push-out of the pellet from the boreholes. This work depends on the friction coefficient between the pellet and channel wall, the length of the channel and the elastic-plastic behavior of the material at the given pressure. This work should also be determined experimentally.
Concerning constant deformation velocity, the particular phases of a compaction process is illustrated in Fig. 1. Due to the constant deformation rate, the pressure increases progressively. During constant load or stress, the deformation and compaction continues to grow (creep). After unloading the elastic part of the deformation, it recovers suddenly followed by a retarded rebound. Much of the deformation is retained as permanent deformation ensuring the required pellet density.

\section{MATERIALS AND METHODS 3. MATERIJAL I METODE}

In order to get industrial sized pellets $(20-30 \mathrm{~mm}$ in length), the design of the experimental equipment should fulfill some basic requirements (Carlos et al., 2010). A plunger type, cylinder and ram, compaction unit was chosen with three diameters of 6,8 and 16 $\mathrm{mm}$. Its length was $150 \mathrm{~mm}$ enabling to use the required volume of loose material to get $20-30 \mathrm{~mm}$ pellet length (Fig. 2a). The outer face of the cylinder could have been heated to a given temperature, using proper thermo-regulating equipment (Fig. 2b). An Instron universal testing machine served as a loading device. The loading velocity was generally $1 \mathrm{~cm} / \mathrm{min}$, which more or less corresponds to the real industrial condition.

Chips of softwood (spruce - Picea abies) and hard wood (Black locust - Robinia pseudoacacia), having different strength properties, were used in these experiments. In order to get a more uniform chip size distribution, a chipper was used and thereafter the samples were sieved into fractions. In these experiments, fractions of 0.063 to $0.2 \mathrm{~mm}, 0.2$ to $0.5 \mathrm{~mm}$ and 0.8 to $1.0 \mathrm{~mm}$ were used. For sieving, an electromagnetic sieve shaker was used with 10 minutes shaking duration at $1.5 \mathrm{~mm}$ amplitudes.

The moisture content of chips was between 10 and $12 \%$ corresponding to the air-dried condition and also to the requirement of getting durable pellets.

Completing the compaction process, the bottom of the cylinder is removed and the pellet is pushed out from the cylinder measuring the required force as a function of displacement. The integral of this force along the displacement gives the work done during the push-out cycle of the pellet.

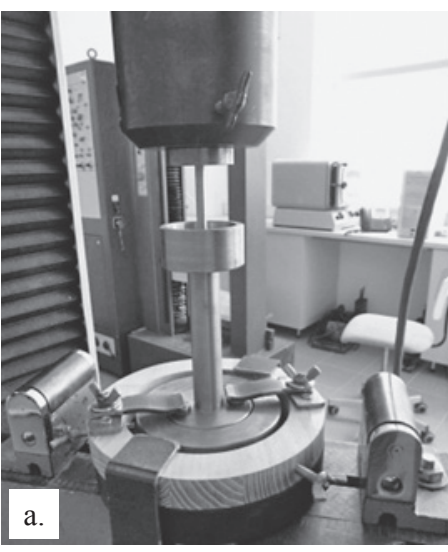

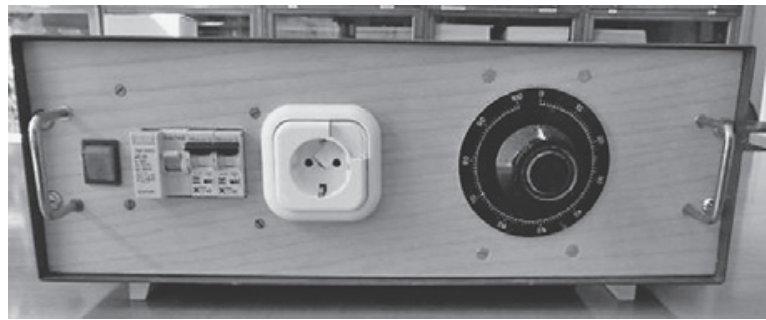

b.

Figure 2 Punch and temperature control and measurement system

Slika 2. Uređaj za peletiranje te sustav za kontrolu i mjerenje temperature 


\section{RESULTS AND DISCUSSION}

\section{REZULTATI I RASPRAVA}

Figure 3 shows the total specific work for spruce chips for different pellet diameters using $140 \mathrm{MPa}$ pressure. With increasing diameters, the relative contribution of wall friction decreases and therefore the energy requirement also decreases.
Using pellet heating with different temperatures, the viscoelastic properties of wood materials change considerably. Figure 4 shows the effect of pellet temperature on the total specific compaction energy.

The beneficial effect of heating is more efficient, however, only up to $100-110^{\circ} \mathrm{C}$, while further increase of temperature reduces the energy requirement in a lesser extent. A possible explanation for this may be the

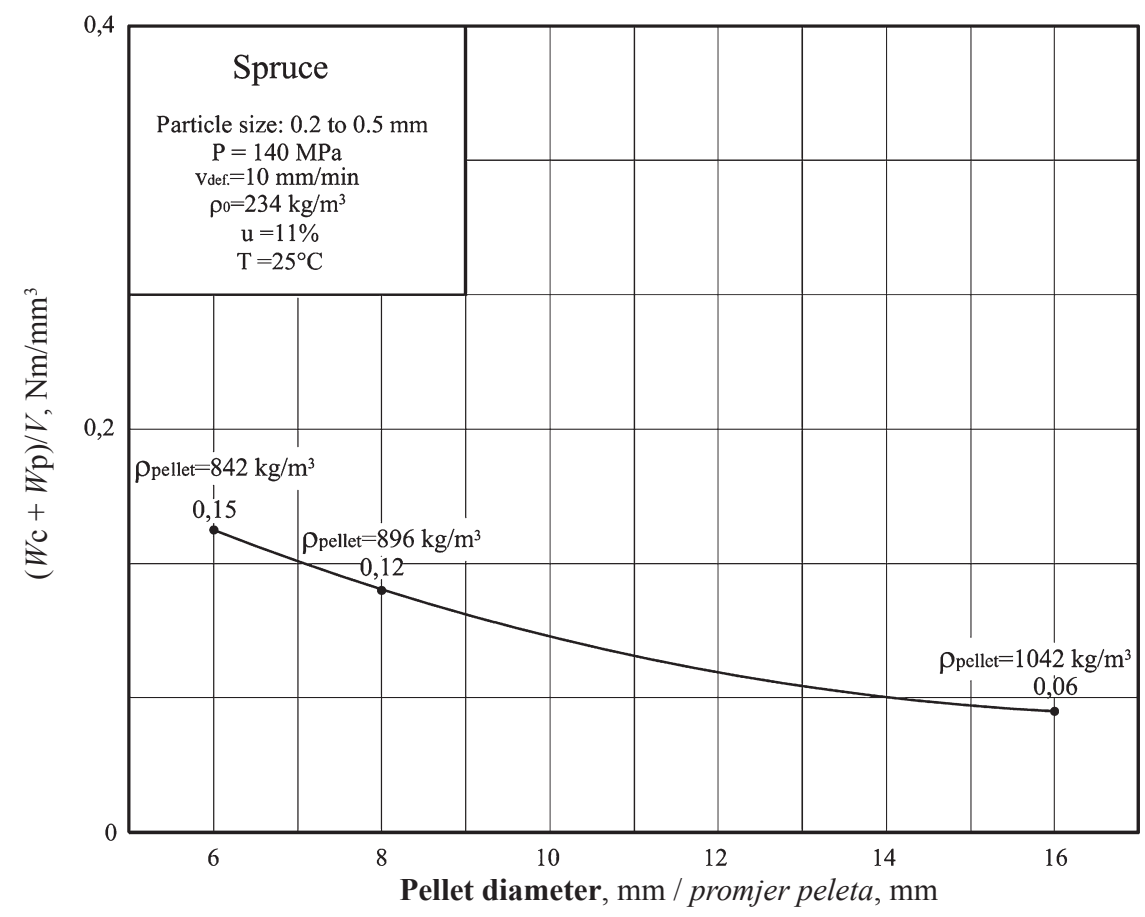

Figure 3 The change in specific work depending on the diameter of spruce pellets at ambient temperature Slika 3. Promjena specifičnog rada u ovisnosti o promjeru peleta od smrekovine pri ambijentalnoj temperaturi

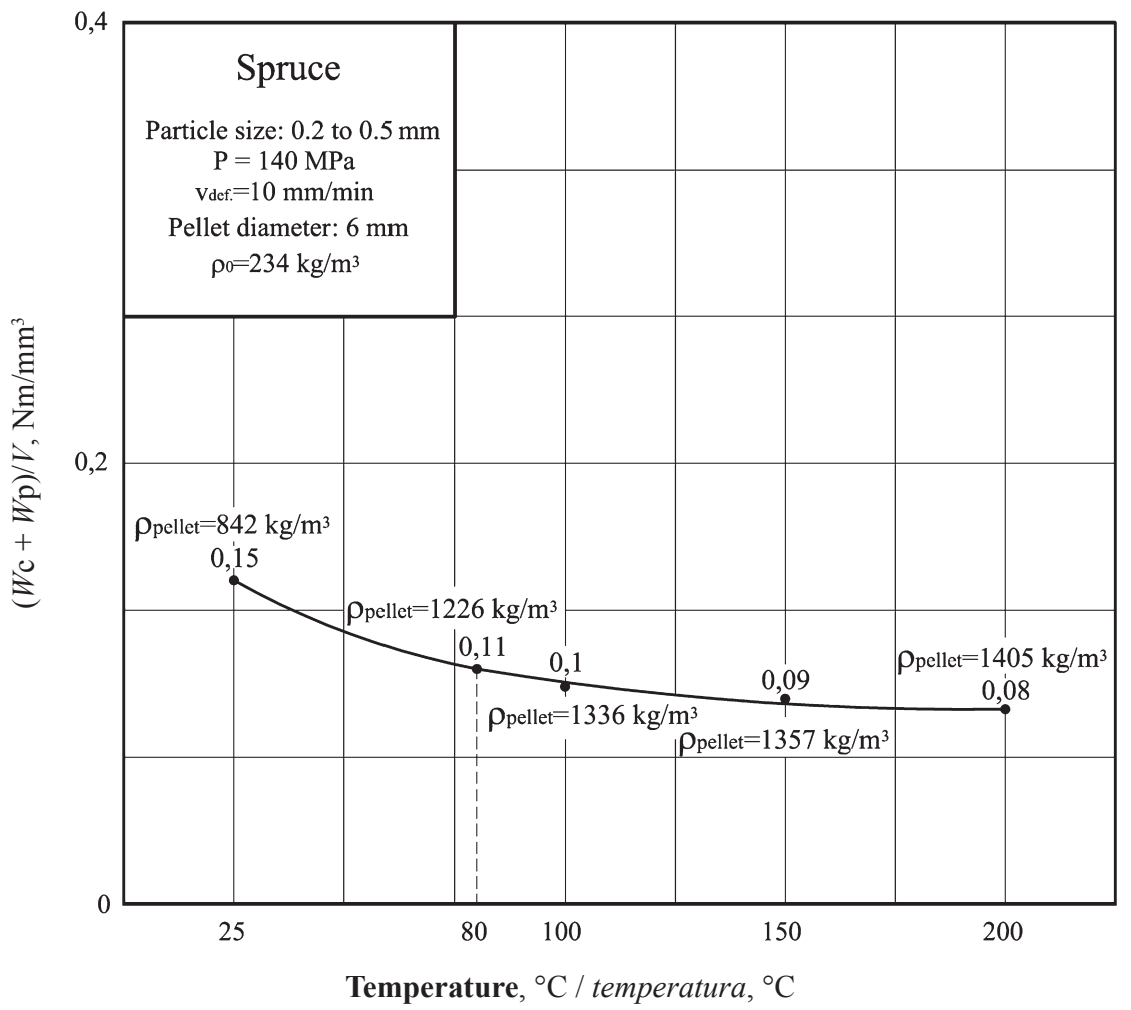

Figure 4 The change of total specific work depending on pellet temperature using spruce chips

Slika 4. Promjena ukupnoga specifičnog rada u ovisnosti o temperaturi peleta izrađenoga od smrekova iverja 


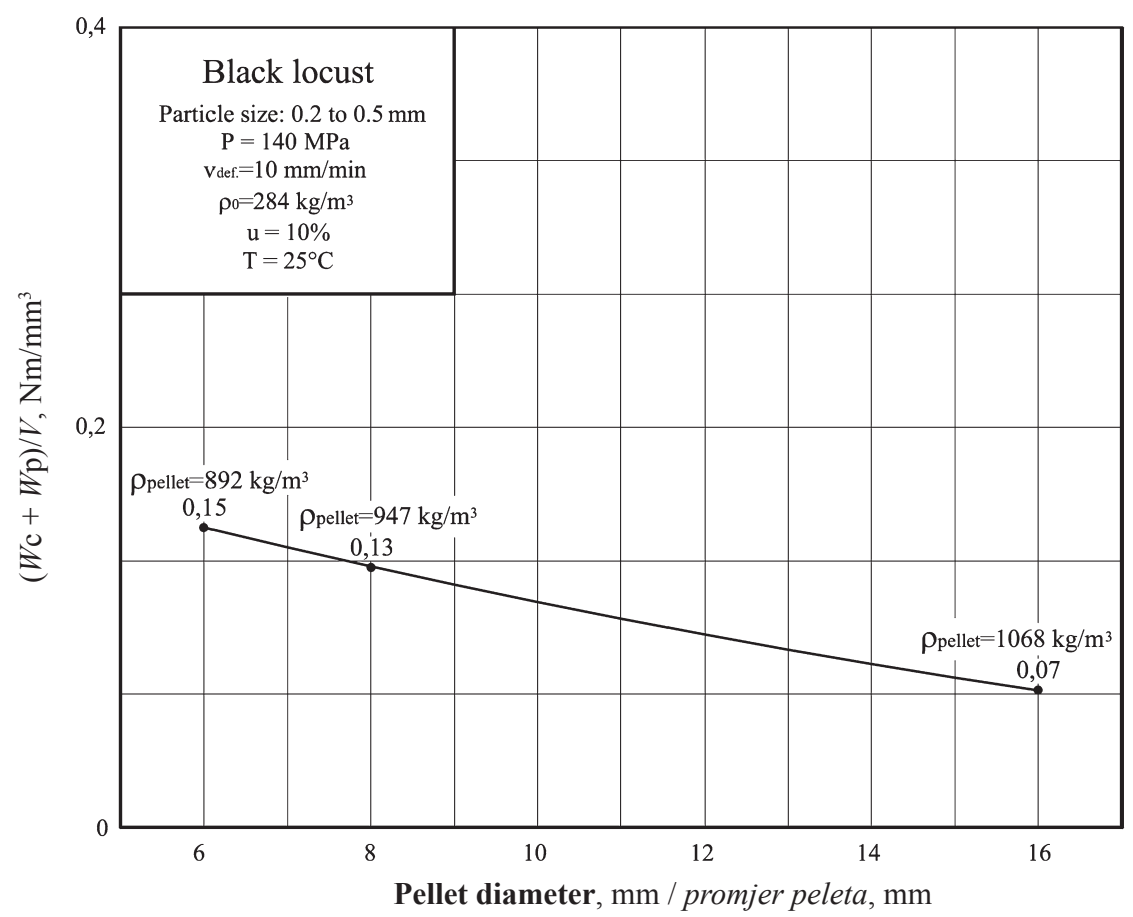

Figure 5 The change in specific work as a function of the punch diameter using black locust samples Slika 5. Promjena specifičnog rada u ovisnosti o promjeru peleta izrađenoga od drva običnog bagrema

reduction in friction coefficient between particles and in the virtual viscosity of the material as the temperature increases. Due to the limiting effect of solid wood density on the compaction process, however, the compaction is an asymptotic phenomenon with decreasing effectivity toward high densities. An inspection of Fig. 4 and Fig. 6 clearly shows that the pellet density over $100{ }^{\circ} \mathrm{C}$ is not far from the solid wood density. It should also be remembered that the pellet density, due to the rebound, is always less than the compaction density at maximum pressure.

Similar measurement results are depicted in Figure 5 and 6 for black locust.

It is interesting to note that the total energy values of compaction for black locust differ only slightly from those of spruce, although the components are not the

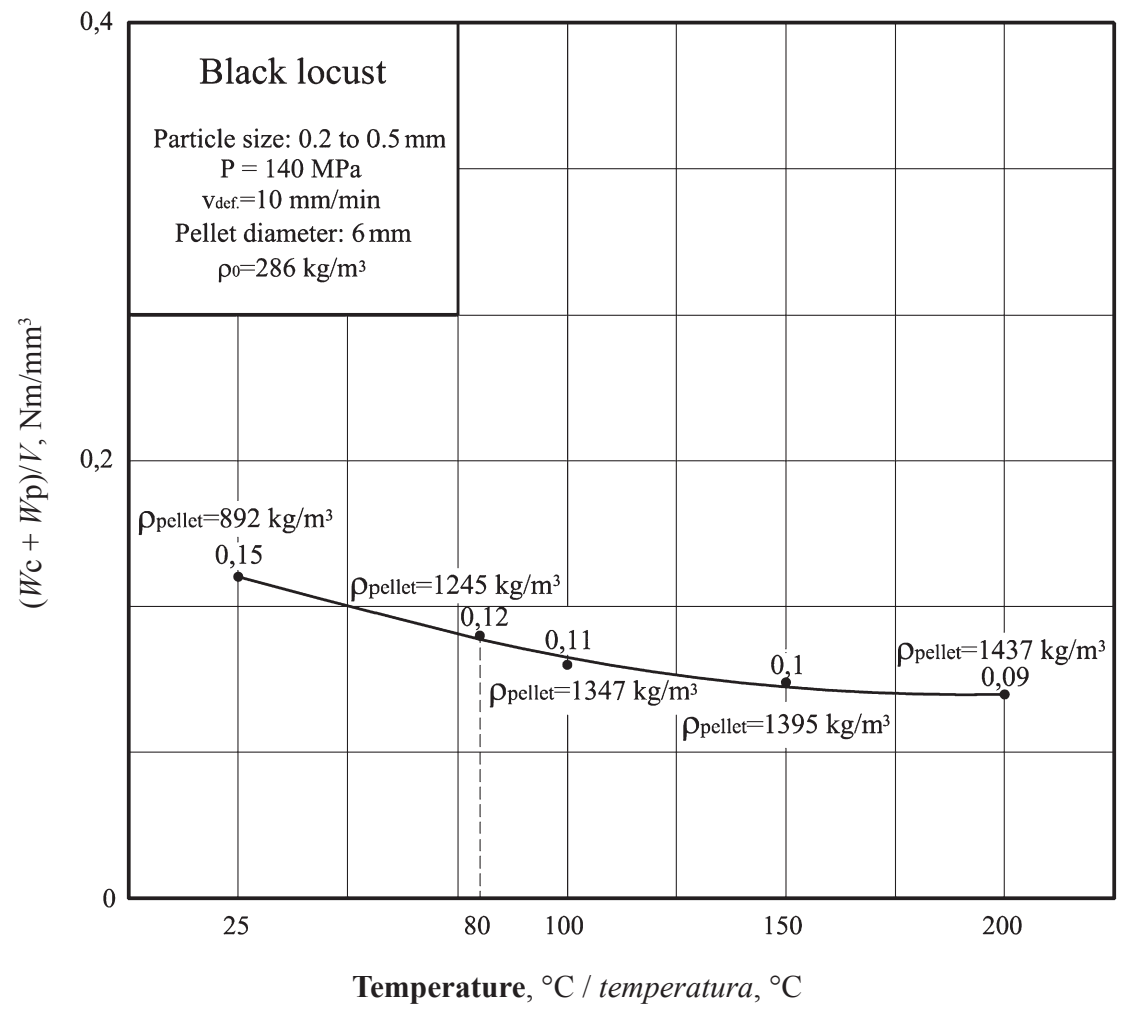

Figure 6 The change in the specific work as a function of temperature using black locust chips Slika 6. Promjena specifičnog rada u ovisnosti o temperaturi peleta izrađenoga od drva običnog bagrema 
Table 1 Summary of research findings in the 100 and 140 MPa pressure range with 0.2 to $0.5 \mathrm{~mm}$ particle sized pellets at $25^{\circ} \mathrm{C}$ Tablica 1. Sažetak rezultata istraživanja pri tlaku prešanja 100 i $140 \mathrm{MPa}$ i za pelete izrađene od drvnih čestica veličine 0,2 $-0,5 \mathrm{~mm}$ pri $25^{\circ} \mathrm{C}$

\begin{tabular}{|c|c|c|c|c|c|c|c|c|}
\hline \multirow[t]{2}{*}{$\begin{array}{c}\text { Species } \\
\text { Vrsta } \\
\text { drva }\end{array}$} & $\begin{array}{c}\text { Pressure } \\
\text { Tlak } \\
\\
p \\
\end{array}$ & $\begin{array}{c}\begin{array}{c}\text { Specific } \\
\text { energy } \\
\text { Specifični rad }\end{array} \\
W \\
\end{array}$ & $\begin{array}{c}\begin{array}{c}\text { Specific } \\
\text { energy } \\
\text { Specifični rad }\end{array} \\
W \\
\end{array}$ & \multirow[t]{2}{*}{$W / p$} & $\begin{array}{c}\text { Pellet specific } \\
\text { gravity } \\
\text { Specifična težina } \\
\text { peleta } \\
\gamma \\
\end{array}$ & $\begin{array}{c}\text { Pellet } \\
\text { diameter } \\
\text { Promjer peleta } \\
d \\
\end{array}$ & $\sigma_{\mathrm{C}}$ & \multirow[t]{2}{*}{$\gamma \cdot \mathbf{d} / \sigma_{\mathrm{C}}$} \\
\hline & $\mathrm{N} / \mathrm{m}^{2}$ & $\mathrm{Nm} / \mathrm{mm}^{3}$ & $\mathrm{Nm} / \mathrm{m}^{3}$ & & $\mathrm{~N} / \mathrm{m}^{3}$ & $\mathrm{~m}$ & $\mathrm{~N} / \mathrm{m}^{2}$ & \\
\hline \multirow{6}{*}{$\begin{array}{c}\text { black } \\
\text { locust } \\
\text { obični } \\
\text { bagrem }\end{array}$} & $1.4 \cdot 10^{8}$ & 0.15 & $1.5 \cdot 10^{8}$ & 1.07 & 8920 & 0.006 & $65 \cdot 10^{6}$ & $8.93 \cdot 10^{-7}$ \\
\hline & $1.4 \cdot 10^{8}$ & 0.13 & $1.3 \cdot 10^{8}$ & 0.93 & 9470 & 0.008 & $65 \cdot 10^{6}$ & $11.65 \cdot 10^{-7}$ \\
\hline & $1.4 \cdot 10^{8}$ & 0.07 & $0.7 \cdot 10^{8}$ & 0.50 & 10680 & 0.016 & $65 \cdot 10^{6}$ & $26.28 \cdot 10^{-7}$ \\
\hline & $1.0 \cdot 10^{8}$ & 0.12 & $1.2 \cdot 10^{8}$ & 1.20 & 8130 & 0.006 & $65 \cdot 10^{6}$ & $7.50 \cdot 10^{-7}$ \\
\hline & $1.0 \cdot 10^{8}$ & 0.10 & $1.0 \cdot 10^{8}$ & 1.00 & 8340 & 0.008 & $65 \cdot 10^{6}$ & $10.26 \cdot 10^{-7}$ \\
\hline & $1.0 \cdot 10^{8}$ & 0.05 & $0.5 \cdot 10^{8}$ & 0.50 & 9720 & 0.016 & $65 \cdot 10^{6}$ & $23.92 \cdot 10^{-7}$ \\
\hline \multirow{6}{*}{$\begin{array}{l}\text { spruce } \\
\text { smreka }\end{array}$} & $1.4 \cdot 10^{8}$ & 0.15 & $1.5 \cdot 10^{8}$ & 1.07 & 8420 & 0.006 & $55 \cdot 10^{6}$ & $9.18 \cdot 10^{-7}$ \\
\hline & $1.4 \cdot 10^{8}$ & 0.12 & $1.2 \cdot 10^{8}$ & 0.86 & 8960 & 0.008 & $55 \cdot 10^{6}$ & $13.03 \cdot 10^{-7}$ \\
\hline & $1.4 \cdot 10^{8}$ & 0.06 & $0.6 \cdot 10^{8}$ & 0.43 & 10420 & 0.016 & $55 \cdot 10^{6}$ & $30.31 \cdot 10^{-7}$ \\
\hline & $1.0 \cdot 10^{8}$ & 0.12 & $1.2 \cdot 10^{8}$ & 1.20 & 7030 & 0.006 & $55 \cdot 10^{6}$ & $7.67 \cdot 10^{-7}$ \\
\hline & $1.0 \cdot 10^{8}$ & 0.09 & $0.9 \cdot 10^{8}$ & 0.90 & 7500 & 0.008 & $55 \cdot 10^{6}$ & $10.90 \cdot 10^{-7}$ \\
\hline & $1.0 \cdot 10^{8}$ & 0.05 & $0.5 \cdot 10^{8}$ & 0.50 & 8450 & 0.016 & $55 \cdot 10^{6}$ & $24.58 \cdot 10^{-7}$ \\
\hline
\end{tabular}

same. In order to calculate the dimensionless numbers, the compressive strength of the wood species used are needed. In general, this value varies for spruce in the range of 45 to $55 \mathrm{~N} / \mathrm{mm}^{2}$ and for black locust in the range of 60 to $65 \mathrm{~N} / \mathrm{mm}^{2}$ (Molnár, 1999). It should be noted, however, that the strength ratio for small particles is not exactly the same as for the solid wood. Therefore, a slight correction might be required. The measured and calculated values for spruce and black locust are summarized in Table 1.

Plotting the dimensionless numbers has revealed that in our case the selection of compressive strength values of 55 and $65 \mathrm{~N} / \mathrm{mm}^{2}$ for spruce and black locust, respectively, is appropriate and all measurement points are on the same line as shown in Figure 7.

The next step was to include the measurement results for different temperatures. The summary of measured and calculated data is given in Table 2 .

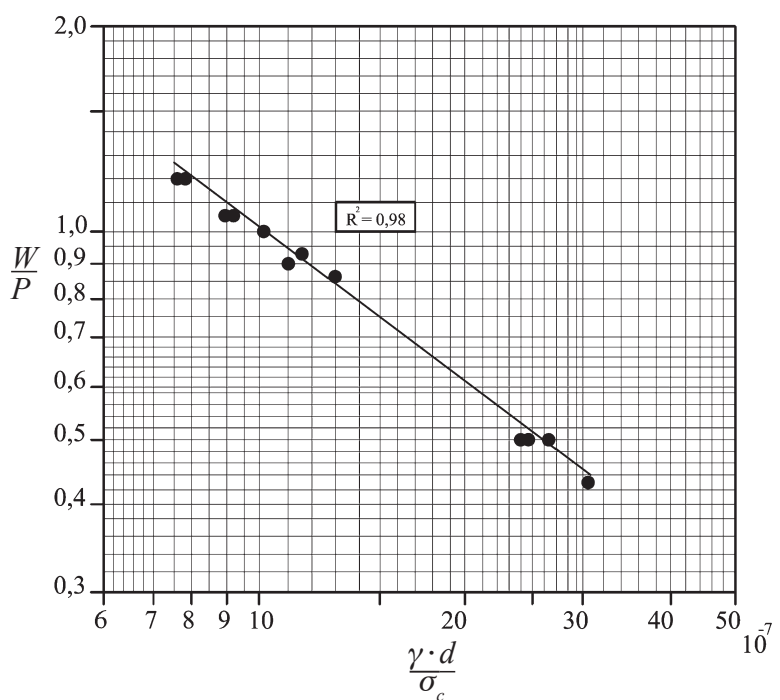

Figure 7 Dimensionless plot of experimental results for ambient temperature

Slika 7. Bezdimenzionalni graf eksperimentalnih rezultata pri ambijentalnoj temperaturi
The exponent $m$ in Eq. (1) should be determined such that the measured points for different pellet temperatures fit the same line properly as given in Figure 7. Taking $m=0.15$, all measurement points including also those for heated pellets fit the straight line as shown in Figure 8.

The scattering zone of measurement points is fully acceptable and it corresponds to a good engineering accuracy. The calculated correlation coefficient is around 0.97 .

In the following, the effect of particle size on the compression work was examined. For these experiments, three fractions of chips were used for both spruce and black locust. The fractions had the following particle ranges: 0.063 to $0.2 \mathrm{~mm}, 0.2$ to $0.5 \mathrm{~mm}$ and 0.8 to $1.0 \mathrm{~mm}$. The measurement and calculated results are plotted in Figure 9 and 10. It is clearly seen that in both cases the energy requirement changes in a very low extent, although the slight decrease for both wood

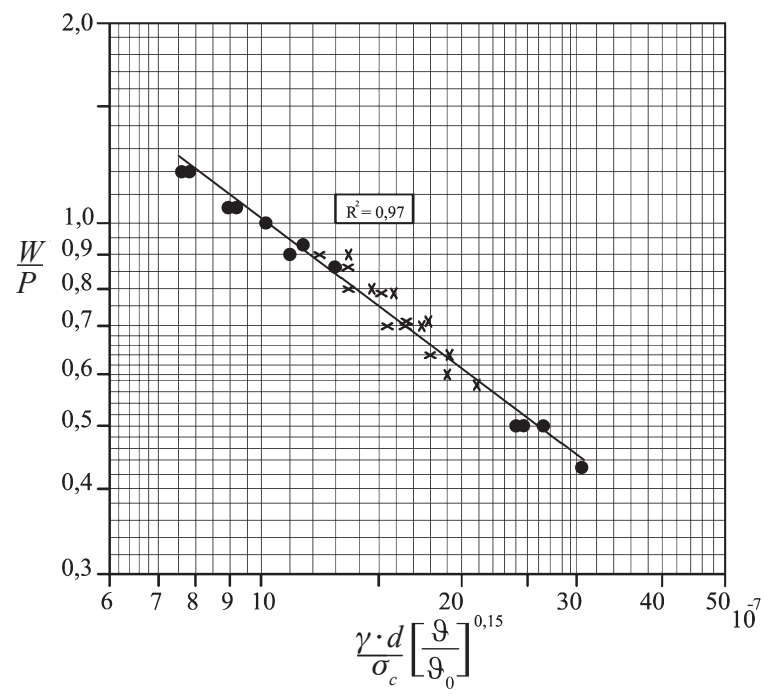

Figure 8 Measurement points including also those for heated pellets

Slika 8. Mjerne točke uključujući i one za grijane pelete 
Table 2 Summary of measured and calculated results at 100 and $140 \mathrm{MPa}, 0.2$ to $0.5 \mathrm{~mm}$ size particles with the effect of the temperature

Tablica 2. Sažetak izmjerenih i izračunanih rezultata istraživanja pri tlaku prešanja 100 i $140 \mathrm{MPa}$ i za pelete izrađene od drvnih čestica veličine $0,2-0,5 \mathrm{~mm}$ uz učinak temperature

\begin{tabular}{|c|c|c|c|c|c|c|c|c|}
\hline \multirow[t]{3}{*}{$\begin{array}{c}\text { Species } \\
\text { Vrsta drva }\end{array}$} & $\begin{array}{c}\text { Pressure } \\
\text { Tlak }\end{array}$ & \multirow{3}{*}{$\begin{array}{c}\text { Specific } \\
\text { energy } \\
\text { Specifični } \\
\text { rad } \\
W \\
\mathrm{Nm} / \mathrm{mm}^{3} \\
\end{array}$} & \multirow{3}{*}{$\begin{array}{c}\text { Specific } \\
\text { energy } \\
\text { Specifični } \\
\text { rad } \\
W \\
\mathrm{Nm} / \mathrm{m}^{3}\end{array}$} & \multirow[t]{3}{*}{$W / p$} & $\begin{array}{l}\text { Pellet specific } \\
\text { gravity } \\
\text { Specifična } \\
\text { težina peleta }\end{array}$ & $\begin{array}{c}\text { Pellet } \\
\text { diameter } \\
\text { Promjer } \\
\text { peleta } \\
\end{array}$ & \multirow[b]{3}{*}{$\mathrm{N} / \mathrm{m}^{2}$} & \multirow[t]{3}{*}{$\left(\frac{\gamma \cdot \mathrm{d}}{\sigma_{\mathrm{C}}}\right) \cdot\left(\frac{\vartheta}{\vartheta_{0}}\right)^{0,15}$} \\
\hline & $\mathrm{p}$ & & & & $\gamma$ & $\mathrm{d}$ & & \\
\hline & $\mathrm{N} / \mathrm{m}^{2}$ & & & & $\mathrm{~N} / \mathrm{m}^{3}$ & $\mathrm{~m}$ & & \\
\hline \multirow{8}{*}{$\begin{array}{c}\text { black locust } \\
\text { obični } \\
\text { bagrem }\end{array}$} & $1.4 \cdot 10^{8}$ & 0.12 & $1.2 \cdot 10^{8}$ & 0.86 & 12450 & 0.006 & $65 \cdot 10^{6}$ & $13.67 \cdot 10^{-7}$ \\
\hline & $1.4 \cdot 10^{8}$ & 0.11 & $1.1 \cdot 10^{8}$ & 0.79 & 13470 & 0.006 & $65 \cdot 10^{6}$ & $15.29 \cdot 10^{-7}$ \\
\hline & $1.4 \cdot 10^{8}$ & 0.10 & $1.0 \cdot 10^{8}$ & 0.71 & 13950 & 0.006 & $65 \cdot 10^{6}$ & $16.74 \cdot 10^{-7}$ \\
\hline & $1.4 \cdot 10^{8}$ & 0.09 & $0.9 \cdot 10^{8}$ & 0.64 & 14370 & 0.006 & $65 \cdot 10^{6}$ & $18.04 \cdot 10^{-7}$ \\
\hline & $1.0 \cdot 10^{8}$ & 0.09 & $0.9 \cdot 10^{8}$ & 0.90 & 11200 & 0.006 & $65 \cdot 10^{6}$ & $12.30 \cdot 10^{-7}$ \\
\hline & $1.0 \cdot 10^{8}$ & 0.08 & $0.8 \cdot 10^{8}$ & 0.80 & 11960 & 0.006 & $65 \cdot 10^{6}$ & $13.58 \cdot 10^{-7}$ \\
\hline & $1.0 \cdot 10^{8}$ & 0.07 & $0.7 \cdot 10^{8}$ & 0.70 & 12870 & 0.006 & $65 \cdot 10^{6}$ & $15.44 \cdot 10^{-7}$ \\
\hline & $1.0 \cdot 10^{8}$ & 0.07 & $0.7 \cdot 10^{8}$ & 0.70 & 13110 & 0.006 & $65 \cdot 10^{6}$ & $16.46 \cdot 10^{-7}$ \\
\hline \multirow{8}{*}{$\begin{array}{l}\text { spruce } \\
\text { smreka }\end{array}$} & $1.4 \cdot 10^{8}$ & 0.11 & $1.1 \cdot 10^{8}$ & 0.79 & 12260 & 0.006 & $55 \cdot 10^{6}$ & $15.91 \cdot 10^{-7}$ \\
\hline & $1.4 \cdot 10^{8}$ & 0.10 & $1.0 \cdot 10^{8}$ & 0.71 & 13360 & 0.006 & $55 \cdot 10^{6}$ & $17.92 \cdot 10^{-7}$ \\
\hline & $1.4 \cdot 10^{8}$ & 0.09 & $0.9 \cdot 10^{8}$ & 0.64 & 13570 & 0.006 & $55 \cdot 10^{6}$ & $19.24 \cdot 10^{-7}$ \\
\hline & $1.4 \cdot 10^{8}$ & 0.08 & $0.8 \cdot 10^{8}$ & 0.57 & 14050 & 0.006 & $55 \cdot 10^{6}$ & $20.84 \cdot 10^{-7}$ \\
\hline & $1.0 \cdot 10^{8}$ & 0.09 & $0.9 \cdot 10^{8}$ & 0.90 & 10520 & 0.006 & $55 \cdot 10^{6}$ & $13.65 \cdot 10^{-7}$ \\
\hline & $1.0 \cdot 10^{8}$ & 0.08 & $0.8 \cdot 10^{8}$ & 0.80 & 11100 & 0.006 & $55 \cdot 10^{6}$ & $14.89 \cdot 10^{-7}$ \\
\hline & $1.0 \cdot 10^{8}$ & 0.07 & $0.7 \cdot 10^{8}$ & 0.70 & 12360 & 0.006 & $55 \cdot 10^{6}$ & $17.53 \cdot 10^{-7}$ \\
\hline & $1.0 \cdot 10^{8}$ & 0.06 & $0.6 \cdot 10^{8}$ & 0.60 & 12860 & 0.006 & $55 \cdot 10^{6}$ & $19.08 \cdot 10^{-7}$ \\
\hline
\end{tabular}

species has the same tendency. If these additional data are used in the similarity equation without any correction and plotted quite similarly to Figure 7 and 8, Figure 11 is obtained including all measurement points.

The scattering of data points is not much higher and in this case the correlation coefficient is also as high as 0.96 . This is also due to the fact that for the construction of Figure 7 and 8, the middle fraction of the three fractions was used and therefore, the points of the other two fractions are placed on the opposite sides of the resultant straight line. The final similarity equation is given in the following form:

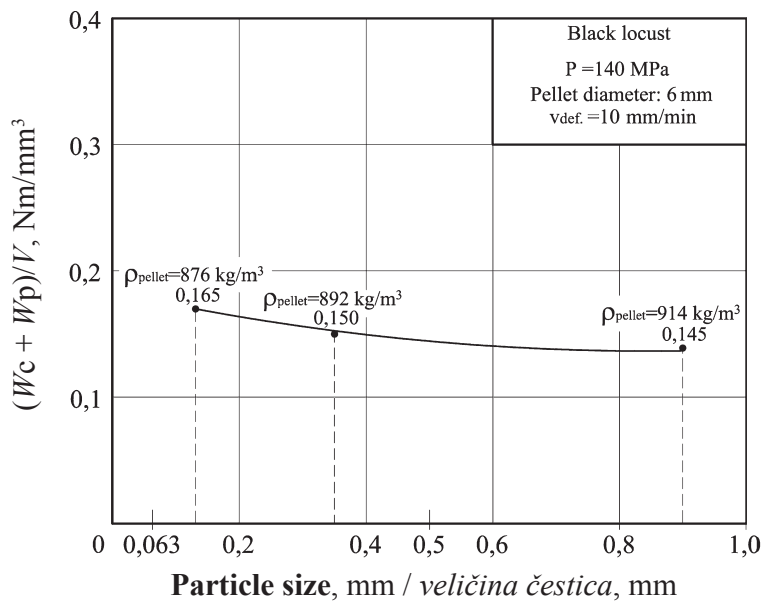

Figure 9 The change in the specific work as a function of particle size using black locust

Slika 9. Promjene specifičnog rada u ovisnosti o veličini čestica usitnjenog drva bagrema

$$
\frac{W}{p}=C \cdot\left(\frac{\gamma \cdot d}{\sigma_{C}}\right)^{-0,75} \cdot\left(\frac{\vartheta}{\vartheta_{0}}\right)^{0,15}
$$

where the constant $C$ has the value of $3.12 \cdot 10^{-5}$

It should finally be noted that in these experiments a plunger with bottom face was used. In practice, however, due to the continuous operation requirements, the chip material is pressed into the boreholes of a die ring and the counter-force is assured by friction forces. Therefore, the push-out force is more or less the same as the maximum compression force. This means that under real conditions somewhat higher specific energy is required.

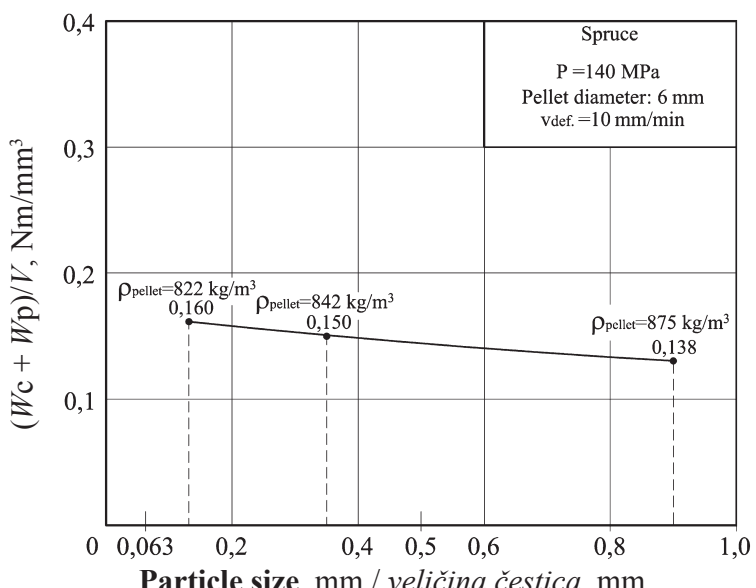

Figure 10 The change in the specific work as a function of particle size using spruce samples

Slika 10. Promjene specifičnog rada u ovisnosti o veličini čestica usitnjenog drva smreke 
Table 3 Summary of measurement results at $140 \mathrm{MPa}$ pressure and with three different particle fractions: 0.063 to $0.2 \mathrm{~mm}$, 0.2 to $0.5 \mathrm{~mm}$ and 0.8 to $1.0 \mathrm{~mm}$

Tablica 3. Sažetak mjernih rezultata pri tlaku $140 \mathrm{MPa}$ i za tri različite frakcije veličine čestica: $0,063-0,2 \mathrm{~mm}, 0,2-0,5$ $\mathrm{mm}$ i $0,8-1,0 \mathrm{~mm}$

\begin{tabular}{|c|c|c|c|c|c|c|c|c|}
\hline \multirow[t]{2}{*}{$\begin{array}{c}\text { Species } \\
\text { Vrsta drva }\end{array}$} & $\begin{array}{c}\text { Pressure } \\
\text { Tlak } \\
\\
p\end{array}$ & $\begin{array}{c}\begin{array}{c}\text { Specific } \\
\text { energy } \\
\text { Specifični rad } \\
W\end{array}\end{array}$ & $\begin{array}{c}\text { Specific } \\
\text { energy } \\
\text { Specifični rad } \\
W\end{array}$ & \multirow[t]{2}{*}{$W / p$} & $\begin{array}{c}\text { Pellet specific } \\
\text { gravity } \\
\text { Specifična težina } \\
\text { peleta } \\
\gamma \\
\end{array}$ & $\begin{array}{c}\text { Pellet } \\
\text { diameter } \\
\text { Promjer } \\
\text { peleta } \\
d \\
\end{array}$ & $\sigma_{\mathrm{C}}$ & \multirow[t]{2}{*}{$\gamma \cdot d / \sigma_{C}$} \\
\hline & $\mathrm{N} / \mathrm{m}^{2}$ & $\mathrm{Nm} / \mathrm{mm}^{3}$ & $\mathrm{Nm} / \mathrm{m}^{3}$ & & $\mathrm{~N} / \mathrm{m}^{3}$ & $\mathrm{~m}$ & $\mathrm{~N} / \mathrm{m}^{2}$ & \\
\hline \multirow{3}{*}{$\begin{array}{c}\text { black locust } \\
\text { obični bagrem }\end{array}$} & $1.4 \cdot 10^{8}$ & 0.165 & $1.65 \cdot 10^{8}$ & 1.18 & 8760 & 0.006 & $65 \cdot 10^{6}$ & $8.08 \cdot 10^{-7}$ \\
\hline & $1.4 \cdot 10^{8}$ & 0.150 & $1.5 \cdot 10^{8}$ & 1.07 & 8920 & 0.006 & $65 \cdot 10^{6}$ & $8.93 \cdot 10^{-7}$ \\
\hline & $1.4 \cdot 10^{8}$ & 0.145 & $1.45 \cdot 10^{8}$ & 1.04 & 9140 & 0.006 & $65 \cdot 10^{6}$ & $8.74 \cdot 10^{-7}$ \\
\hline \multirow{3}{*}{$\begin{array}{l}\text { spruce } \\
\text { smreka }\end{array}$} & $1.4 \cdot 10^{8}$ & 0.160 & $1.6 \cdot 10^{8}$ & 1.14 & 8220 & 0.006 & $55 \cdot 10^{6}$ & $8.96 \cdot 10^{-7}$ \\
\hline & $1.4 \cdot 10^{8}$ & 0.150 & $1.5 \cdot 10^{8}$ & 1.07 & 8420 & 0.006 & $55 \cdot 10^{6}$ & $9.18 \cdot 10^{-7}$ \\
\hline & $1.4 \cdot 10^{8}$ & 0.138 & $1.38 \cdot 10^{8}$ & 0.99 & 8750 & 0.006 & $55 \cdot 10^{6}$ & $9.54 \cdot 10^{-7}$ \\
\hline
\end{tabular}

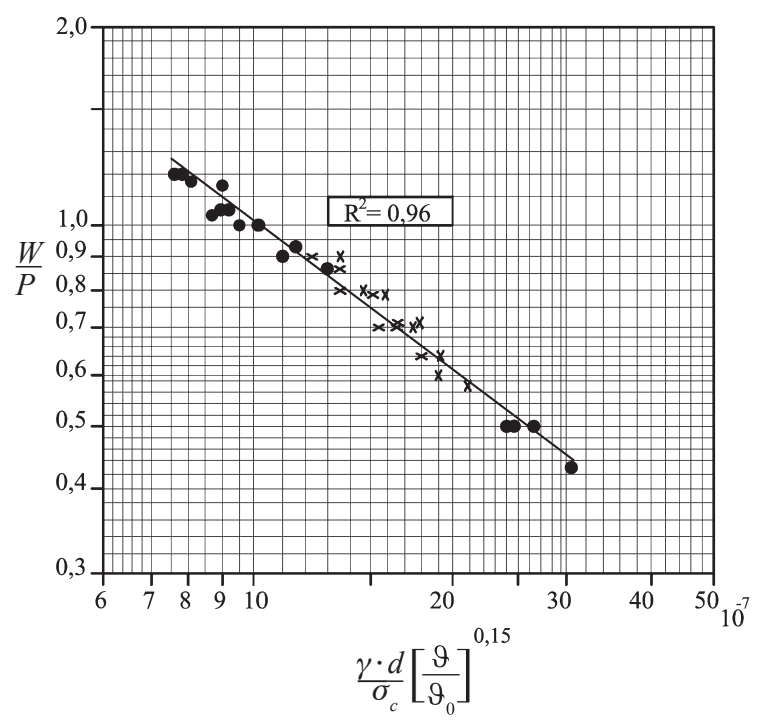

Figure 11 The final similarity plot of all measurement results

Slika 11. Konačni graf sličnosti za sve mjerne rezultate

\section{CONCLUSIONS}

\section{ZAKLJUČAK}

Based on theoretical and experimental investigations, the following main conclusions may be drawn:

- The main influencing factor is the pellet diameter, which fundamentally determines the role of wall friction forces in the total energy requirement;

- The heating of chips during pellet formation seems to be advisable up to $100{ }^{\circ} \mathrm{C}$. Above this temperature limit, its effect continuously decreases;

- The chip size distribution has some effects on the energy requirement but, disregarding its effect, it does not cause significant error;

- Using similarity equation is a powerful method to generalize experimental results also for compaction processes. In this way a simple and quick estimation of energy requirement is possible.

\section{REFERENCES}

\section{LITERATURA}

1. Akdeniz, R. C.; Haghighat, S., 2013: The effect of die dimensions, raw material moisture content and particle size on pelletizing characteristics of olive cake. Department of Agricultural Machinery, International Conferences Engineering, Agriculture, Waste Management and Green Industry Innovation. Gödöllő, Hungary, 13-19. October, p. 33-41.

2. Buckingham, E., 1914: On the physically similar systems. Physical Review (4), p. 345. http://dx.doi.org/10.1103/PhysRev.4.345

3. Carlos, S.; Tore, F.; Geir, S.; Odd-Ivar, L.; Olav, H.; Reidar, B., 2010: Compression rheology and physical quality of wood pellets pre-handled with four different conditions. Annual Transactions of the Nordic Rheology Society, Norwegian, 14: 152-168.

4. Csanády, E.; Magoss, E., 2013: Mechanics of Wood Machining. Springer-Verlag Berlin Heidelberg 2013, p. 2530. http://dx.doi.org/10.1007/978-3-642-29955-1

5. Hofko, B., 2008: Rheologische Modelle zur Beschreibung des Verformungsverhaltens von Asphalten. p. 98-112.

6. Langhaar, H., 1951: Dimensional analysis and theory of models. John Wiley London. p. 25-34.

7. Molnár, S., 1999: Faanyagismerettan [Wood material science]. Mezőgazdasági Szaktudás Kiadó, Budapest. p. 292. (in Hungarian).

8. Pronk, C., 2005: The Huet-Sayegh Model; a Simple and Excellent rheological Modell for Master Curve of Asphaltic Mixes. Geotechnical Special Publication No. 146. Asphalt Concrete. p. 115-185.

9. Sitkei, Gy., 1994: Non-linear rheological method describing compaction processes. Int. Agrophysics, pp.137142.

10. Sitkei, Gy., 1997: A non-linear viscoelastic-plastic model describing compaction processes. Proc. of the 2nd Int. Conf. of IMACS/IFAC Budapest, pp.105-112.

11. Schwanghart, H., 1969: Messung und Berechnung von Druckverhältnissen und Durchsatz in einer RingkollerStrangpresse. Aufbereitungs-Technik, p. 713-722.

\section{Corresponding address:}

\section{Professor ETELE CSANÁDY, Ph.D.}

Institute of Machinery and Mechatronics

University of West Hungary

Bajcsy-Zs. u. 4.

H-9400 Sopron, HUNGARY

e-mail: etele.csanady@skk.nyme.hu 